\title{
NEW DIMENSIONS OF TURKISH CAPITAL MARKETS: FUNDING SMALL AND MEDIUM-SIZED ENTERPRISES
}

\author{
Prof. Dr. Halil Sarıaslan \\ Sermaye Piyasası Kurulu \\ Kurul Üyesi
}

\section{Özet}

\section{Türkiye Sermaye Piyasasının Yeni Boyutlan: Küçük ve Orta Ölçekli İsletmelerin Fonlanmast}

Bu makale küçük ve orta ölçekli işletmelerin (KOBI'lerin) ulusal ekonomilerdeki önemini ele almakta ve Türkiye ekonomisindeki KOBt'lerin karşılaştıklan finansal sorunlan çözmek için ụ̧̈ temel seçenek sunmaktadır. Bu amaçla, önce KOBl'lerin ekonomik sistemlere olan genel katkılan açklanmaktadır. Ekonomide değer üreten ve istihdam sağlayan temel ekonomik birimler olarak oldukça önemli rollerine karşın, Türkiye'deki KOBl'ler yanlş ekonomik politikaların sonucu olarak mevcut finansal sistem tarafindan devamlı olarak yaratılan büyük finansal problemlerle karşılaşmaktadırlar. Bu sorunları hafifletmek için özkaynak yatınm fonlarının kurulması, önce bölgesel düzeyde ve daha sonra ulusal düzeyde bütünleştirilmiş OTC piyasalarının oluşturulması ve KOBI'lerin ticari bankalardan talep ettiği kredilere teminat veren kredi garanti fonlarının kurulması biçiminde üç seçenek sunulmaktadur. Bu üç seçeneğin ya da yaklaşımun aynı anda uygulamaya konulması ile Türkiyede finansal sistemde etkin bir finans kesitinin oluşturulacağı öne sürülmektedir. Böylece KOBl'lerin piyasa ekonomisi kurallarına göre finansal sorunlarının üstesinden gelebileceklerine ve artık hükümetler tarafından çok sınırl olarak verilen düşük faizli fonları beklemeyeceklerine inanılmaktadır.

\section{Abstract}

This article deals with the importance of small and medium-sized enterprises (SMEs) in national economies, and provides three main options to solve the financial problems that SMEs in the Turkish economy face. Despite their crucial role in the economy, as value producing and employment providing essential economic entities, the SMEs in Turkey encounter huge financial problems that are continuously created by the existing financial system as a result of mislcading economic policies. In order to mitigate the problems three possibilities; namely establishing private equity funds, forming OTC markets first at regional level and then combining them at national level, and establishing credit guarantee funds to secure the loans requested by SMEs from the commercial banks, are presented. It is asscrted that if these three approaches are put into practice concurrently, they would form an efficient segment of the financial system in Turkey such that SMEs would overcome their financial problems according to the rules of a market economy and that they have no longer to wait for the very limited subsidized funds that will be provided by governments. 


\section{New Dimensions of Turkish Capital Markets: Funding Small and Medium-Sized Enterprises}

\section{The Importance of Small and Medium Scaled Enterprises in Economic Systems:}

Small and medium-scaled enterprises (SMEs) do not operate in a vacuum. Like all economic entities they operate in an economic system that both affects them and, in turn, is affected by them. In general, in almost all countries the SME sector is the largest and the most important component of the economic system since in almost all economies between 95 and 99 percent of all enterprises are small and medium-scaled enterprises. On the other hand, the efficiency of an economic system as a mechanism for allocating and utilizing scarce resources depends to a large extent on the degree of competition it maintains. In other words, the existence of competition in a market economy is a "sine qua non" condition for economic efficiency. Furthermore, as it is generally accepted, competition motivates human creativity and, thus, provides dynamism for an economy, which both are essential for economic and technological development.

From this viewpoint, it can be stated that in addition to their commonly known basic functions of producing economic value, or a value added in the largest sense of the term, and generating employment in the least costly way; the most important contribution of SMEs to an economy is their ability of promoting competition and, thus, providing dynamism to the economy. The reasons for this contribution or the competition effect of SMEs on the economic systems are various.

First, as indicated above, in almost all national economies SMEs constitute more than $95 \%$ of all business enterprises and, thus, the efficiency of their economic activities is considered to be the barometer of the viability of economic systems within which they operate. As such, in a competitive market economy SME sector forms a business forest which is composed of numerous SMEs (trees) of which some will decay (close down), some will survive and some will grow, 
challenge and replace large businesses enterprises (LITTLE/MAZUMDAR/ PAGE, 1987).

Secondly, as generally known, an economy that is dominated and completely controlled by large business enterprises neither can refrain itself from being oscillated nor can protect itself from being degenerated in the long run. The rational way of maintaining the viability of an economy is through competition which is eventually provided by the existence of a large SME sector, since small business owners tend to be achievement oriented, as opposed to managers of large firms, who tend to be power and prestige oriented. The owners of small businesses have a strong sense of enterprise that gives them a desire to use their ideas, abilities and aspirations to the greatest degree possible. They are able to conceive new ideas, plan them, carry them to a successful conclusion, and profit from the results of those plans. This is a rare case in large businesses (MEGGINSON/SCOTT/MEGGINSON, 1991).

Thirdly, the basic characteristics of small business owners are known to be the drive for achievement, the desire of independence and the willingness to work long and hard to reach their goals. They are capable, ambitious, persevering individuals. Therefore, the most peculiar entrepreneurial personality trait of small business owners is the "drive" to achieve (MEGGINSON/SCOTT/MEGGINSON, 1991). It is this drive of achievement and the desire of independence that leads SMEs or their owners to compete with and challenge large firms and that, in turn, result in promoting competition and providing dynamism for an efficient market economy.

Needless to indicate that the degree of competition maintained in an economy is determined by the economic policy in general and the small business policy in particular followed by a country, and that all economic units in a national economic system are exposed to the social, political and economic regulations and policies which the governments of that nation or country adopt and implement. However, the impact of these regulations and policies is much greater and more influential on the SME sector since most of SMEs are small and weak in nature. That is, small businesses are fragile economic entities and, therefore, are more open to the effects of governmental regulations and socio-economic policies in their process of establishment and struggle to survive and grow. Economic policies in general and small business policies in particular create an environment or a climate that would induce the establishment of new small businesses (start-ups) as well as stimulate the existing SMEs to compete in order to grow. For this reason, a brief evaluation of economic and small business policies of Turkey is given below. 


\section{Macro Economic Policies Affecting SMEs in Turkey:}

The most important factor to initiate a business in a market economy is undoubtedly the ability of combining the factors of production, which is referred to as entrepreneurship by economists. The concept of entrepreneurship is an integral part of an individual's personality, which is assumed to a certain extent to be the result of the socio-economic and cultural environment in which the individual lives.

From this general point of view, it could be stated that the conditions surrounding the business life were not that much favorable to create an adequate business environment in Turkey until 1980. Having restructured its political and economic system in 1920's, Turkey started a state led economic development program due to the lack of private capital formation. Lots of state-owned economic enterprises were established by following an import-substitute industrialization policy until 1950's. However, a more liberal and market oriented economic policy was launched in 1950, but ended up with a military coup d'état in 1960 . Turkey, then, turned back again to follow a state controlled economic development program determined by the Five-Year Development Plans, which were mandatory for the governmental institutions and state-owned companies to observe. This economic policy through state controlled and planned economic development programs and import-substitute industrialization process was followed until 1980.

Although during the period between 1960 and 1980 various economic achievements were realized, a favorable business environment was not formed so that creative and innovative entrepreneurs would evolve. The widespread use of state incentives (heavily subsidized credits) and the practice of state control and protection in foreign trade to create a national type of entrepreneur resulted in establishing a large number of state supported industrial enterprises. However, a large number of these enterprises went through very deep crises because of mismanagement mostly stemming from lack of managerial skills and professionalism as well as political interventions by the governments. Within such a heavily state dominated and controlled economic and business environment it was rather difficult to expect individuals to start and establish their own businesses, since in such an economic environment people would behave with a security motive that would lead them continuously to work for the state rather than become entrepreneurs or have their own independent businesses. The result of such an economic environment with almost no competition was no doubt a weak SME sector that always needed the support and aid from the state.

This general outlook of the economic environment surrounding business enterprises before 1980 has started changing gradually. After 1980 the Turkish 
economy has gone through some radical changes. A lot of economic and financial changes and arrangements, that were geared to establish an export led market economy, have taken place within the last two decades. The interest rate and foreign exchange policies which were dictated and heavily controlled by the state and that the industrialization policies based on import substitution and dominance of state-owned enterprises were steadily transformed into more liberal financial and export led economic policies after the year 1980, which is considered to be a major turning point in the Turkish economy. A series of changes and measures that constituted a stabilization and liberalization program were introduced by the support of multilateral organizations including IMF and the World Bank. The general goals of the programs and the policies followed thereafter were first to reduce inflation and secondly to promote exports and liberalize imports. The third goal was financial liberalization aiming at liberalizing foreign capital movements and making the Turkish Lira a convertible currency. A fourth important purpose that underlined the characteristics of the stabilization programs and the policies implemented was to reduce the role of the public sector in the economy by downsizing the state and privatizing the state-owned enterprises.

1980s have also witnessed many decisive attempts and institutional innovations aiming at increasing competition in the financial markets. In 1981, the Capital Market Board was established to regulate, supervise and develop the primary and secondary capital markets. The Istanbul Stock Exchange (IMKB) was reorganized and reopened in 1986. IMKB has made good progress and the volume of transactions increased continuously so that it has attracted foreign investors after 1989. The 1980 s were actually the period during which many new financial institutions were introduced to Turkey and that considerable developments were achieved. Leasing companies, Istanbul Gold Exchange, increases in numbers as well as sizes of insurance and reassurance companies are some of these examples. The introduction of new financial institutions to Turkey has continued by the establishment of one venture capital firm by Vakıf Bank (Vakuf Risk A.S.).

Undoubtedly, the results of those changes and arrangements have been a more liberal economy through which Turkey accomplished, on the average, a growth rate of 5 percent in GNP within the last two decades, increased its exports ten times and imports six times, and realized an industrialization process that made possible the portion of industrial products in exports to rise from 36 percent to 88 percent, not to mention the emergence a dynamic small and medium-sized enterprise sector which has contributed significantly to the development of a more competitive market economy. The Turkish experience in the industrialization process, in turn, has once more proved that what business firms need to evolve and prosper is actually an adequate and free entrepreneurial environment rather than the protection and control of the state. 
Moreover, as indicated by many studies, the most important outcome of those changes and arrangements has been a more liberal economy in which young people preferred more to have their own business and to work for privately owned companies as opposed to holding a job in the government offices or state owned companies.

Notwithstanding the fact that the Turkish economy has accomplished great achievements after 1980s in terms of exports, foreign currency reserves, GNP as well as industrial growth; however, due mainly to the lack of decisive governmental actions, political instability, and adequate legislative arrangements enabling structural changes for implementing liberal economic policies, the Turkish economy has faced some severe economic problems such as chronic high inflation, high interest rates, and unstable economic growth. Although between the years 1990 and 1998 some stabilization programs were planned and partly implemented to reduce the budget deficits by downsizing the government, lowering wages, cutting down public expenditures, increasing tax revenues, privatizing state-owned enterprises etc.; unfortunately, the desired results were not realized simply because of political instability and populist policies followed by the governments elected.

The privatization programs that were prepared and planned long ago by various governments failed. The arrangements proposed to the parliament to extend the work period in order to prevent employees from retiring at early ages were not enacted by the parliament. Thus, the state-owned enterprises and social security institutions still suck public funds and constitute a heavy burden on the budget. Therefore, what the Turkish economy has been suffering from since 1980 is actually a prolonged economic instability that has brought about an instable political environment, which, in turn, has further accelerated the economic instability, a nested vicious circle. The Turkish society in general and business community in particular has been well aware of the causes behind the economic instability. Therefore, the need for some radical economic structural changes has been stated loudly by the whole society, since it is believed that Turkey would not accomplish a stable economic development and, thus, a competitive industry unless the necessary structural changes are made.

Being aware of this strong public demand and pressure for structural changes and facing the huge amount of budget deficit as well as its resultant problems, the coalition government that took office after the elections in April 1999 has started to take the necessary measures to reduce budget deficits and keep under control the high inflation in the economy. Some of these important measures include: significant changes in tax law to increase revenues and an amendment to social security law to extend the work period of employees in order to prevent retirement at early ages, enacting a new banking law and changing the security market law to ensure a reliable financial system, preparing 
a comprehensive and realistic privatization program to rationalize the market mechanism, declaring and implementing a tight monetary policy and a controlled exchange rate program to reduce inflation to a targeted level of 25 percent in the year 2000 and then 10 percent in 2001, lowering the wages of public employees in line with the targeted inflation rate, and signing a three year stand-by agreement with IMF to ensure reducing the budget deficit.

All these measures added to the harmonious work of the coalition government give a lot of hope to the Turkish society as well as the business community that political stability would be maintained and that our economy would be functioning, at last this time, according to the rules of a rational market mechanism so that the inherent dynamics of the country would be activated to utilize its great potential in order to develop and foster rapidly. There are good reasons and signs of change that the Turkish economy, which is the 17th largest economy of the world according to the World Bank statistics and a member of the G 20 countries, is heading for a much more better future that the Turkish people deserved long ago.

\section{Small Business Policy of Turkey:}

Not withstanding the fact that what micro and small businesses need to evolve and prosper is actually an adequate and free entrepreneurial environment rather than the protection of the state; however, no significant measures regarding SMEs were taken during 1980s. Turkey did not even have a clearly determined economic policy for small businesses. Although the Tradesmen and Craftsmen Law numbered 507 was enacted in 1964, tradesmen and craftsmen were always regarded as persons engaging in traditional micro and small businesses such as grocery stores, carpentry, shoe making, licensed taxi driving, auto repairs, dry cleaning, etc., and also as those groups of people who have always needed the protection and support of the state, as indicated by the Article 173 of the Constitutional Law which mandates that the State takes protecting and supporting measures for tradesmen and craftsmen.

Almost 15 years later, in the Fourth Five Year Development Plan (1979 1983), the term small industry was for the first time defined separately from the traditional terms of tradesmen and craftsmen. Then, in 1983 the Small Industry Development Center (KÜSGEM) was turned into the Small Industry Development Organization called KÜSGET in order to provide consultancy services in technology, finance, organizational development and management for small business firms. Additionally, the Tradesmen and Craftsmen Law numbered 507 was amended in 1985 to focus on the contents, organization, control and financing of the practical vocational - technical education for small businesses. 
Subsequently, as the idea of providing educational and technical consultancy services for fostering entrepreneurial skills of the small business owners gains impetus in the development policy of Turkey, this tendency led to the creation of a much larger organization which was called as KOSGEB (Administration for Developing and Supporting Small and Medium Scaled Industry). KOSGEB was established by merging KÜSGET and SEGEM in 1990. KOSGEB has totally confined its activities to provide technical support for SMEs according to its law. Therefore, no attention was paid to financing SMEs. The whole burden of financing SMEs was left on the shoulders of Halk Bank, a public bank that was officially charged with providing finance for SMEs. Although this bank has done its best to fund SMEs with various kinds of subsidized loans; however, due to the shortage of its loanable funds Halk Bank has been unable to meet all loan requests made by SMEs. As such, the share of all SMEs in the total loans provided by the Turkish banking system is at best estimated to be around 8 percent.

As seen from the preceding explanations, it took a lot of time for the Turkish authorities to grasp the idea that small businesses actually need the creation of an adequate and competitive business environment rather than the state protection and help in order to foster. As it is indicated in a study conducted by the Union of Chambers and Commodity Exchanges of Turkey (TOBB), the existing financial system of Turkey is discriminating against small business firms and that all the problems that these firms face today are due to the state controlled and led economic policies that have been followed so far (SARIASLAN, 1996). At this point it should be indicated that the economic policy changes which have taken place since 1980 to form a market economy have ameliorated the business climate for small and medium-sized businesses to evolve and foster a bit more easily. However, there is still a long way to go.

\section{Financial Problems and Financing of SMEs: Some Approaches and New Dimensions for Funding Them:}

Despite their crucial role and important functions in an economy as well as their social role as a security mechanism by preserving the social order through providing employment and creating jobs in the least costly way, SMEs, which account for $99.8 \%$ of all businesses in Turkey, presently face some significant problems related to financing. These financial problems of SMEs could be specified as: (i) shortage of loanable funds in the economy to finance long term capital investments, (ii) reluctance of banks to lend SMEs due to higher transaction costs, (iii) lack of collateral to secure loans from commercial banks, and (iv) almost no access to capital markets to raise funds (SARIASLAN, 1996). Despite some sporadic efforts to tackle the growing financial problems of 
SMEs, these firms still suffer from severe financial problems because they have very limited access to financial resources when needed.

As revealed by a research study conducted for TOBB, about 61 percent of SMEs indicated that they deeply needed additional financing. On the other hand, although the majority of them needed financing, most of the SMEs $(71 \%)$ stated that they did not borrow loans from commercial banks due mainly to high interest rates on loans, time consuming bureaucratic formalities, lack of social relations to get in touch with bank managers to start the process (thinking that banks lend only to those SMEs that they know well), and lack of collateral required to secure or guarantec the loans. Moreover, among those SMEs that answered they borrowed from banks (29\%) a large portion of them $(55 \%$ of 29 $\%)$ indicated that they encountered various difficulties when they borrowed (SARIASLAN, 1996).

Therefore, it could easily be stated that some decisive measures have to be taken so as to enable SMEs to overcome these financial problems and to have access to financial resources when they need them. In countries where SMEs operate in a favorable competitive environment and have direct access to financial resources when they need, SMEs perform well and accommodate to changing conditions rapidly, because one of the basic advantages they have over large companies is their flexibility in their economic activities. As such, what Turkey should do to have their SMEs to keep up with the changing conditions of the competitive world economy is to remove barriers for SMEs to have direct access to sources of funds when a need arises and that to encourage them to benefit from the opportunities provided by financial markets.

The experience of some developed countries reveals that there are some well-known approaches so as to provide opportunities for SMEs to have access to financial markets. The practices of Small Business Investment Companies, Over-The-Counter (OTC) Market, and Credit Guarantee Funds in the western world, for instance in USA and Germany, are such approaches that could be easily adaptable to the Turkish financial markets and that, in turn, would add a new dimension to their development. A brief explanation of these approaches in terms of their possible implementation in Turkey is given below.

\section{SME Equity Participation Funds:}

The proposition of SME equity participation funds is mostly drawn from the USA practice of small business investment companies (SBICs). For this reason a brief explanation of the SBIC model is needed. As it is known, according to the Small Business Investment Act of 1958, SBICs in USA are privately owned financial firms that are licensed by Small Business Administration (SBA) according to a set of well defined requirements in terms of 
the amount of private capital, qualified personnel, investment activities, geographical area of operation, etc. Having been licensed a SBIC is entitled to borrow from SBA or issue bonds secured by SBA up to 200 or 300 percent (special SBICs) of its private paid-in capital. SBICs can only make loans to and \or invest in stocks of SMEs whose fields of operation or economic sectors are defined by SBA previously. The investment activities of SBICs in SMEs are clearly determined by SBA and that they are not allowed to engage in any other economic activity. In short, their basic purpose is to provide private capital financing for SMEs through the support of SBA.

In 1993 the Union of Chambers of Commerce, Industry, and Commodity Exchanges of Turkey (TOBB) adopted this SME financing approach of USA and suggested the government at that time implement it in Turkey in order to solve the financial problems of SMEs (SARIASLAN, 1993). However, the Turkish public authorities in charge of financing SMEs might have not appreciated the idea that they have not prepared so far any regulation that is necessary for such a practice. Later on in 1998, TOBB, together with its 21 large chambers and a public bank (Halk Bank), decided to implement the SBICs approach in the form of a private equity fund which was named SME Equity Participation Fund (KOBI Yatmmlarına Ortaklık A.Ş.). The basic purpose of the Fund is to provide funds to those dynamic SMEs with high growth potential on a partnership basis not exceeding $30 \%$ share of the firm.

After the investment is completed and that the participated SME has reached to a certain level of growth and profitability that is considered appropriate by the fund management, the participated SME is expected and helped to register with a security exchange so as to go public. Upon selling its share of stocks either in the capital market or to the major partner of the SME or to a third party, the fund management quits its interest in the SME with which its investment was tied up for some three or five years. The Fund is active and is now in the process of raising additional funds and evaluating possible alternatives for investment in SMEs. However, due mainly to the limited amount of paid-in private capital (around USD 2500000) and difficulties of raising funds in capital markets because of negative macro economic conditions prevailing in the country, the fund management is presently hesitant to start and expand its investment activities, since the demand from SMEs which all are members of chambers of TOBB is quite high.

At this point it should be mentioned that the Treasury has finally shown some interest in this practice of financing SMEs by providing a very limited support through its planned Incentive Scheme for SMEs in the year 2000. Even though the incentives that are to be provided for SME equity participation fund (s) by the Treasury are negligible, TOBB still appreciates this as a gesture since one of the aims of establishing the Fund was to introduce this approach of SME 
financing to the Turkish financial system and to conduce the establishment of some other private equity funds by financial institutions so as to speed up the real capital investments in the Turkish economy.

In sum, it is our strong assertion that by developing an adequate legal regulatory environment and providing some meaningful incentives for SME equity participation funds, as in USA practice of SBICs, the Turkish capital market will definitely gain some new financial institutions and evolving dimensions in overcoming financial problems of SMEs to a significant extent. This will also lead to the creation of an appropriate environment for venture capital firms, which are certainly needed for technological development, to increase in number and size.

\section{Over-The-Counter Market:}

As it is the case in all developed countries, in order to protect individual investors security exchange commissions set forth some strict rules and regulations for business firms that want to register with organized security exchanges so as to issue securities. To meet the needs of those business firms, which are unable to satisfy the requirements of security exchange commissions so as to issue securities in capital markets, the so-called over-the-counter (OTC) markets with relatively loose registration and quotation requirements are formed in developed countries, NASDAQ being the most developed and well known one.

However, there is no such possibility in Turkey and, thus, SMEs have almost no access to capital markets because of not being able to meet the registration rules of Capital Market Board (SPK) and the quotation regulations of Istanbul Stock Exchange (IMKB). In spite of the fact that IMKB has established recently some new security exchange segments named New Companies Market and Regional Markets in its premises to help SMEs and new companies to raise funds in capital market; nonetheless, they have been unsuccessful in terms of attracting business firms. As the need for paving the way for SMEs to have access to capital markets has increased, in December 1999 an amendment to the Capital Market Law has mandated the formation and establishment of an Over-The-Counter (OTC) market by the Capital Market Board (SPK) to enable SMEs to issue securities for raising funds in the Turkish capital market. SPK is now in the process of establishing such a market.

Our personal viewpoint is that OTC market practice in Turkey should start as a pilot work at provincial or regional level. That is, firstly, two or three provinces where SMEs are heavily concentrated should be selected and regional OTC markets should be formed separately in each selected location or region. Secondly, having gained experience and streamlined the operation of these pilot 
regional OTC markets, the implementation should be extended to all other potential provinces. No doubt that, such an attempt that would start as a pilot implementation on a regional basis would eventually lead to the formation of a national OTC market similar to that well known example of NASDAQ by simply combining and harmonizing regional OTC markets, which may be called TASDAQ (Turkish Association of Securities Dealers' Automated Quotation) system.

We, therefore, strongly believe that regional OTC markets at the first stage and TASDAQ system at the last stage will not only open up the road for SMEs to capital markets but also contribute significantly to the progress and enlargement of IMKB, since business firms being registered with TASDAQ will subsequently go to IMKB which is the most prestigious organized exchange at national level. Additionally, the existence of such an OTC market in Turkey will no doubt accelerate the development of SME equity participation funds, private equity funds, and venture capital firms, which all together will increase the speed of real capital investments in the country and bring new dimensions to capital markets.

\section{Credit Guarantee Funds:}

As it was explained in the preceding pages, SMEs in Turkey encounter some significant barriers that restrict heavily their access to financial resources. Lack of collateral to secure loans from banks, is one of these important barriers since the banks in Turkey usually require a collateral equivalent to 200 percent of the size of the loan requested. Therefore, it could easily be asserted that if some appropriate solutions are developed to remove the problems related to collateral, there is no doubt that SMEs access to financial funds will be improved to a certain extent. That is, credit guarantee services play an important role in increasing the accessibility of SMEs to financial resources. From such a realistic viewpoint and also taking into consideration the German experience of credit guarantee funds, a Credit Guarantee Fund Corporation was established according to a technical cooperation agreement signed on July 14, 1993 between Turkey and Germany. It basically aims at providing guarantee or security services for both micro businesses (tradesmen and craftsmen) and SMEs which do not have more than $200 \mathrm{employees}$ and that are unable to provide sufficient security to pledge for the repayment of the loans to be borrowed from banks.

The Credit Guarantee Fund was set up as a business corporation whose shareholders presently are: TOSYÖV (The Foundation of Small and Medium Sized Businesses and Professionals of Turkey), MEKSA (The Foundation for Vocational Education and Small Industry Support), TOBB, TESK (the Confederation of Tradesmen and Craftsmen of Turkey), Halk Bank, and 
KOSGEB; all having equal shares. An initial amount of a liability fund of DM 3.5 millions provided by Germany was deposited in Halk Bank in May 1994 to start the operation of the Credit Guarantee Fund Corporation according to a protocol, which was drafted by Halk Bank and the German Technical Cooperation (GTZ) acting on ! thalf of the Government of Germany. Later on, KOSGEB participated in the Fund with an equal amount of DM 3.5 millions.

The size of the fund is presently DM 6.4 millions, excluding the withdrawals by Halk Bank to recover some bad debts, and all of it is deposited in Halk Bank. The total amount of the guarantee or security that the Fund will be able to provide is DM 32 millions, which is five times of its available liability fund deposited in Halk Bank. The Fund provides guarantee for all types of loans from Halk Bank available for micro, small, and medium-sized businesses. Although the Credit Guarantee Fund Corporation desires to secure loans given to micro, small and medium sized businesses not only by Halk Bank but also by all banks; however, the Fund management has not been able so far to make protocols with the other banks to do so. The Fund has its main office in Ankara and has a branch office in Istanbul. The Fund previously established two branches in Bursa and Izmir. However, they were later closed down on the account of the low level of demand in these regions.

In contrast to the result of our studies or the belief that there is a certain need for credit guarantee services by SMEs, as explained earlier, if one takes into account a guarantee capacity utilization ratio of $52 \%$ and closing down of the formerly established branches of the Fund in Izmir and Bursa due to the low level of demand, it can easily be concluded that the Fund faces some significant problems. The reasons for these problems or the factors preventing the development of the Fund are various and are out of the scope of this paper. However, the most important barrier to the development of the Fund is that of the Fund managers' feeling to lose the existing limited liability fund. Having no state support or any sort of counter guarantee and or reassurance, the fund managers behave very cautiously in their guarantee activities in terms of customer selection and security requirements for the guarantees given. This attitude of risk aversion is a general personality trait of almost all small business managers and/or owners who feel that when they lose they will lose every thing completely, including their jobs. Because they know that in case of any financial difficulty they will neither raise capital nor get any financial support from any source including their sharcholders. Thus, the Credit Guarantee Fund Corporation, like all prudent small businesses, eventually follows an approach to develop step by step and expand steadily. Accordingly, the Fund managers refrain from marketing or promotional activities both not to incur additional operational costs and not to lose the control of the fund. 
In conclusion, it can be definitely stated that the idea of establishing a credit guarantee fund in Turkey has had a very sound base since the need for credit guarantee services has been largely felt by SMEs, as the research studies we conducted and our personal experience have revealed. There is no doubt that this need will continue increasingly in the future. Therefore, there must be found some possible ways or solutions to accelerate the development of the credit guarantee funds in Turkey and to increase their effectiveness, since such funds or financial institutions has a sufficiently large potential market as well as a great contribution to enable SMEs to overcome the barriers preventing them from reaching financial resources available in the market. For this purpose two complementary measures will help a lot: (i) the Treasury has to recognize the credit guarantee funds as financial institutions and (ii) to reassure or provide a counter guarantee system for their guarantees to a certain extent, as it is the case in Germany. There is no need to indicate that the Treasury would have a right to investigate any "moral hazard" issue associated with the lost guarantees. The Treasury may even charge a reassurance or counter guarantee premium for the amount of the guarantees it reassures and collect it in a fund designated for this purpose.

Once this is accomplished we are certain that credit guarantee funds will prosper soon and add a new dimension to the Turkish financial market as well as supporting SMEs reach to financial resources more easily. Additionally, in order to speed up and expand the development of credit guarantee funds so as to meet the credit guarantee needs of SMEs as well as those of micro businesses (tradesmen and craftsmen) efficiently according to the rules of a competitive market economy, a second radical step is needed. And that is to convert or transform the existing Tradesmen and Craftsmen Credit and Security Cooperatives into credit guarantee funds as contemporary financial institutions. The Tradesmen and Craftsmen Credit and Security Cooperatives, which were first established in 1951, operate as financial intermediaries for their members to obtain subsidized loans from Halk Bank by securing the requested loans. Presently, there are 879 credit and security cooperatives throughout Turkey, which are combined under 29 regional Cooperatives Associations. These regional Cooperatives Associations, in turn, form a central organizational body, which is called The Central Union of Tradesmen and Craftsmen Credit and Security Cooperatives Associations of Turkey. In conclusion, if such cooperatives are transformed into credit guarantee funds as contemporary financial institutions operating according to the rules and regulations of a market economy, undoubtedly the financial system in Turkey will have new dimensions that will make it more efficient. 


\section{Conclusion:}

As indicated earlier, SMEs are not only the dynamos of successful economies but they also provide a great security mechanism to preserve the social order in a country, since they are the most essential source of providing employment and creating jobs. Therefore, there must be developed some clear-cut policies to support them to overcome their existing financial problems, to encourage and have them benefit from the opportunities provided by telecommunication technologies, such as electronic trade, and to increase their competitiveness in the globalization process. For this purpose the approaches explained in the forgoing pages might be recommended to support SMEs overcome their financial problems and have access to financial resources.

It is our strong assertion that if these three approaches, namely, SME equity participation funds, regional and then national OTC markets, and credit guarantee funds are put into practice concurrently, they would form an efficient segment of the financial system in Turkey such that SMEs would overcome their financial problems according to the rules of a market economy and that they have no longer to wait for the very limited subsidized funds that will be provided by governments from national elections to elections. SMEs will struggle to survive according to market conditions rather than search for politicians to give them a boost to reach to the state aid. No doubt that all these arrangements and institutions will contribute significantly to the Turkish financial markets to gain new dimensions and to develop more efficiently.

\section{References}

UTTLE, Ian M.D./MAZ(IMDAR, D./PAGE. J.M.Jr. (1987). Small Manufacturing Enterprises: A Comparative Analysis of India and Other Countries (Washington D.C.: The World Bank).

MEGGINSON, L/ SCOTT, C.R./MEGGINSON, W. (1991), Successful Small Business Management (Homewood, lilinois: Irwin).

SARIASLAN. Halil (1996), Türkiye Ekonomisinde Küçūk ve Orta Olçekli Işletmeler (Small and Medium.Scaled Enterprlses in Turkish Economy) (Ankara: TOBB).

SARIASLAN. Halil (1993), Küçük ve Ora Oçekli Işletmelerin Finansal Sonunlan: Çozüm ķin Finansal Bir Paket Onerisi (Financial Problems of Small and Medium-Scaled Enterprlses: A Financial Package for Solution) (Ankara: TOBB). 